\title{
Journal of Clinical \& Cellular Immunology
}

\section{Cholinergic Actions of Autoantibodies from Breast Cancer Patients on Dendritic Cells}

María Gabriela Lombardi ${ }^{1}$, Gabriela Salamone ${ }^{2}$, Soledad Gori ${ }^{2}$, Manuel Alejandro Oroño ${ }^{1}$, Alejandro Javier Español ${ }^{1}$ and María Elena Sales $^{1}$

${ }^{1}$ Centro de Estudios Farmacológicos y Botánicos (CEFYBO)-Segunda Cátedra de Farmacología. Facultad de Medicina, Universidad de Buenos Aires, Paraguay 2155, piso 16, Buenos Aires, Argentina

${ }^{2}$ Instituto de Medicina Experimental (IMEX) CONICET-Academia Nacional de Medicina, Las Heras 3092, Buenos Aires, Argentina

"Corresponding author: María Elena Sales, Centro de Estudios Farmacológicos y Botánicos (CEFYBO)-Segunda Cátedra de Farmacología, Universidad de Buenos Aires, Paraguay 2155, piso 16, Buenos Aires, Argentina, Tel: 005-411-5950-9500; Email: alegazpio@yahoo.com.ar

Received date: May 12, 2015, Accepted date: July 09, 2015, Published date: July 15, 2015

Copyright: (c) 2015 Lombardi GM, et al. This is an open-access article distributed under the terms of the Creative Commons Attribution License, which permits unrestricted use, distribution, and reproduction in any medium, provided the original author and source are credited.

\begin{abstract}
Autoantibodies (autoAbs) against self-proteins have been localized in tumor microenvironment exerting a complex network of interactions. We reported the presence of autoAbs in breast cancer patients, which promote tumor progression by activating muscarinic acetylcholine receptors (mAChR) in tumor cells. Cholinergic receptors are also expressed in dendritic cells (DC) and much clear evidence demonstrated a deficient functional activity of $D C$ in cancer. Here we investigated whether autoAbs can modulate the expression of maturation markers and the production of cytokines by DC. IgG from breast cancer patients in stage I reduced the expression of HLA-DR and CD86 as well as tumor necrosis factor alpha liberation and augmented interleukin IL-12 and IL-10 levels by cholinergic activation of mature DC. The latter cytokines are also up-regulated in patients' sera, probably due to tumor influence, since the addition of breast tumor extract increased cytokine levels in immature DC reaching levels of mature DC mainly for IL-10 and IL-12. It could be assumed that autoAbs are reinforcing the tolerogenic/ immunosuppressive profile mediated by DC in breast cancer.
\end{abstract}

Keywords: Autoantibodies; Breast cancer patients; Dendritic cells; Cholinergic receptors

\section{Introduction}

Breast cancer is the most common malignant neoplasm and a cause of death by cancer among women worldwide. Its development including malignancy grade and patient prognosis is influenced not only by the mutations that suffer tumor cells, but also by the status of the immune system, which interacts with tumor microenvironment [1]. Some authors have reported that the immune system is unable to halt tumor progression and even more it is responsible of promoting tumorigenesis [2]. Innate immune cells, like dendritic cells (DC), natural killer cells, granulocytes, macrophages and monocytes are present in the normal mammary gland and play an important role participating in its development and remodeling, but they are also present in neoplastic tissues, such as breast tumors. This infiltration of innate immune cells in the tumor tissue might be an attempt of the body to Fight against illness [3,4]. DC are the most potent professional antigen presenting cells which can uptake, process, and present different types of antigens, including tumor antigens to antigenspecific naïve T cells [5]. DC act as sentinels of the immune system by efficiently capturing and processing foreign antigens. In the presence of a "danger signal" (such as infection or inflammation), DC shift from an antigen-capturing mode to a T-cell sensitizing mode, a phenomenon called "maturation" which is usually associated with their migration to secondary lymphoid tissues where they provide signals 1-3 to T lymphocytes [5]. In most types of cancers or in animal models of spontaneously arising tumors, instead of being eliminated by the immune response, tumors progress, metastasize, and ultimately, result in death of the host. Much clear evidence has demonstrated a deficient functional activity of DC in cancer [6,7]. Actually, it is increasingly clear that the DC defects in cancer are systemic, and are not localized to tumor tissues [8]. Systemic humoral immune response against different antigens in tumor bearers has been documented [9]. Among these antigens, self-proteins, which are expressed in tumor cells but not at all or only at very low levels in normal cells might therefore function as tumor associated antigens capable of priming the immune system to recognize tumor cells [10]. Therefore, instead of acting as tumor rejecting antigens, they induce tolerance or autoimmune responses $[11,12]$. We have documented that immunoglobulin G (IgG) from breast cancer patients in T1N0Mx (tumor size $<2 \mathrm{~cm}$, without lymph node metastasis) promotes tumor cell proliferation, metalloproteinase activity and angiogenesis via muscarinic acetylcholine receptors ( $\mathrm{mAChR}$ ) activation [13-15]. These receptors, that are highly expressed in breast tumor cells are considered as part of the non-neuronal cholinergic system (nNCS) together with acetylcholine (ACh), choline acetyltransferase and acetylcholinesterase, the enzymes that synthesize and degrade $\mathrm{ACh}$, and nicotinic acetylcholine receptors ( $\mathrm{nAChR}$ ), that also target the action of ACh. We have also reported that nNCS is present in human DC and that mAChR of 3,4 and 5 subtypes are expressed and functional in these cells [16]. Here we investigated the ability of autoAbs to modulate the expression of maturation markers and the production of cytokines by DC through cholinergic receptors' activation.

\section{Materials and Methods}

\section{Selection of patients}

Cancer patients $(\mathrm{n}=32)$ with breast adenocarcinoma in stage I were selected in the Mastology Department of the Angel H. Roffo Oncology Institute, University of Buenos Aires, and were classified according to 
Citation: Lombardi MG, Salamone G, Gori S, Oroño MA, Español AJ, et al. (2015) Cholinergic Actions of Autoantibodies from Breast Cancer

Page 2 of 6

TNM criteria as T1N0Mx (tumor size $\leq 2 \mathrm{~cm}$, without axillary node metastasis). Subjects free of illness (normal) $(n=20)$ were used as controls. All of them were free of treatment, and blood samples (10-20 $\mathrm{ml} /$ donor) were obtained at routine procedures before surgery. Written informed consent was approved by the Ethics in Research Committee from the Angel H. Roffo Oncology Institute, and was obtained from each patient.

\section{IgG purification}

After centrifugation of blood samples, sera were separated and heatinactivated at $56^{\circ} \mathrm{C}$ for $30 \mathrm{~min}$. IgG purification was performed by affinity chromatography in protein G-agarose (Invitrogen Inc., Carlsbad, CA, USA). Samples ( $\mathrm{pH}$ 6.0-7.5) were loaded onto the column after equilibrating it with 10 volumes of binding buffer: 0.01 sodium phosphate $\mathrm{pH} 7.0 ; 0.15 \mathrm{M} \mathrm{NaCl}$ at high salt concentration. Elution was performed with $0.1 \mathrm{M}$ glycine hydrochloride $(\mathrm{pH} 2.6)$ and adjusted immediately to $\mathrm{pH}$ 7.0. Concentration of proteins in the collected fractions was obtained by measuring the absorbance at 280 $\mathrm{nm}$, and fractions that corresponded to the peak of maximal absorbance were stored at $-20^{\circ} \mathrm{C}$.

\section{Generation of human denditic cells}

Blood samples were obtained from 20 healthy non-smoker women donors in the Fundación Hemocentro Buenos Aires, Argentina. Blood was obtained by venipuncture of the forearm vein, and it was drawn directly into heparinized plastic tubes. Mononuclear cells were isolated from peripheral blood by Ficoll-Hypaque $(1.077 \mathrm{~g})$ density gradient centrifugation (GE Healthcare, Uppsala, Sweden). CD14 $4^{+}$cells were then isolated by positive selection according to the manufacturer's instructions (Miltenyi Biotec, Bergisch Gladbach, Germany). The purity was checked by FACS analysis using anti-CD14 monoclonal antibody and was found to be higher than 95\%. To obtain DC, monocytes $\left(10^{6} / \mathrm{ml}\right)$ were cultured in RPMI 1640 medium supplemented with $10 \%$ of heat-inactivated fetal calf serum (FCS) (Gibco, Life Technologies,Grand Island, NY, USA) $50 \mathrm{U} / \mathrm{ml}$ penicillin, $50 \mu \mathrm{g} / \mathrm{ml}$ streptomycin (Invitrogen, Life Technologies, Grand Island, NY, USA), $20 \mathrm{ng} / \mathrm{ml}$ interleukin (IL)-4, and $20 \mathrm{ng} / \mathrm{ml}$ granulocyte macrophage-colony stimulating factor (GM-CSF) (Immunotools, Friesoythe, Germany) during 5 days. To obtain mature DC $(\mathrm{mDC})\left(2 \times 10^{6}\right)$ were cultured with lipopolysaccharide (LPS) from E. coli $(500 \mathrm{ng} / \mathrm{ml})$ during $24 \mathrm{~h}$ at $37^{\circ} \mathrm{C}$. LPS untreated cells were considered as immature DC (iDC) [17]. Before each experimental procedure, cells were treated during $1 \mathrm{~h}$ with $\operatorname{IgG}$ in the absence or presence of cholinergic antagonists (atropine or mecamylamine) added $30 \mathrm{~min}$ before.

\section{Flow cytometry}

Cells were washed twice with phosphate buffer saline (PBS) supplemented with $2 \%$ FCS and suspended in PBS supplemented with $10 \%$ heat-inactivated FCS. Fluorescein isothyocyanate (FITC) and phycoerythrin (PE) conjugated monoclonal antibodies were added at saturating concentrations for $30 \mathrm{~min}$ at $4{ }^{\circ} \mathrm{C}$, and two additional washes were performed. DC were stained with the following monoclonal antibodies: FITC- or PE-conjugated monoclonal antibodies directed to HLA-DR or CD86 respectively (BD Pharmingen, San Diego, CA, USA). Analysis was performed by using a FACS flow cytometer and CellQuest software (BD Biosciences, San Jose, CA, USA).

\section{Measurement of cytokine production}

The production of cytokines: tumor necrosis factor alpha (TNF- $\alpha$ ), IL-12 and IL-10 was measured in cell culture supernatants by ELISA (R\&D Systems, Minneapolis, MN, USA).

\section{Tumor cell extract}

The human breast adenocarcinoma cell line MCF-7 was obtained from the American Type Culture Collection (ATCC; Manassas, VI, USA), and cultured in Dulbecco's modified Eagle's medium and F12 medium (DMEM:F12; 1:1; Invitrogen Inc., Carlsbad, CA, USA) with 2 $\mathrm{mM} \mathrm{L}$-glutamine, $80 \mathrm{mg} / \mathrm{ml}$ gentamycin, supplemented with $10 \%$ heat inactivated $\mathrm{FCS}$ at $37^{\circ} \mathrm{C}$ in a humidified $5 \% \mathrm{CO}_{2}$ air. Cell cultures were maintained as monolayers at $37^{\circ} \mathrm{C}$ and $5 \% \mathrm{CO}_{2}$ in DMEM medium supplemented with $5 \%$ FCS. Confluent monolayers were detached using the following buffer: $0.25 \%$ trypsin and $0.02 \%$ EDTA in $\mathrm{Ca}^{2+}$ and $\mathrm{Mg}^{2+}$ free PBS. The medium was replaced three times a week. Cell viability was assayed by Trypan blue exclusion test, and the absence of mycoplasma was confirmed by Hoechst staining [18]. To prepare cell extracts, detached cells were lysed by triple freezing at $-80^{\circ} \mathrm{C}$ during 10 min alternated with thawing at $20^{\circ} \mathrm{C}$ followed by centrifugation at 3000 rpm during $10 \mathrm{~min}$ [19]. Protein concentration was determined in the supernatants by the method of Bradford [20] and saved at $-20^{\circ} \mathrm{C}$.

\section{Drugs}

All drugs were purchased from Sigma Chemical Co (St. Louis, MI, USA) unless otherwise stated. Solutions were prepared fresh daily.

\section{Statistical analysis}

Results are given as means \pm S.E.M. of at least three independent experiments. The statistical significance of differences between means was calculated by the analysis of variance using GraphPad Prism 5; p $£ 0.05$ was considered to be statistically significant. The analysis was complemented by using the Tukey test to compare among mean values. Differences between means were considered significant if $\mathrm{p}$ $£ 0.05$.

\section{Results}

\section{Effect of IgG on HLA-DR and CD86 expression by dendritic cells}

We have previously reported that IgG from breast cancer patients in T1N0Mx promotes breast tumor progression by activating mAChR. These receptors are also express in DC thus, DC may be sensitive to the action of autoAbs. We analyzed the effect of IgG on DC obtained from human monocytes cultured with IL-4 and GM-CSF for 5 days. Then cells were stimulated with LPS to obtain $\mathrm{mDC}$ or cultured without LPS, yielding iDC. As it was expected, mDC expressed higher amounts of HLA-DR than iDC (Figure 1A). The addition of T1N0MxIgG significantly reduced HLA-DR expression in $\mathrm{mDC}$ at all concentrations tested ( $\mathrm{p}<0.0001$ vs. control) (Figures $1 \mathrm{~A}$ and $2 \mathrm{~A}$ ). This effect was reverted in the presence of $10-8 \mathrm{M}$ atropine but not by mecamylamine (10-7M) (Table 1). Normal-IgG did not modify HLADR expression in DC (Figure 1B). 
Citation: Lombardi MG, Salamone G, Gori S, Oroño MA, Español AJ, et al. (2015) Cholinergic Actions of Autoantibodies from Breast Cancer Patients on Dendritic Cells. J Clin Cell Immunol 6: 340. doi:10.4172/2155-9899.1000340

Page 3 of 6

\begin{tabular}{|l|l|l|l|}
\hline $\begin{array}{l}\text { Maturation Marker } \\
\text { (Fluorescence } \\
\text { intensity units) }\end{array}$ & Treatment & \multicolumn{2}{|l|}{} \\
\cline { 2 - 4 } IgG $\left(10^{-8} \mathrm{M}\right)$ & $\operatorname{IgG}+\mathrm{AT}\left(10^{-8} \mathrm{M}\right)$ & $\operatorname{IgG}+\mathrm{MM}\left(10^{-7} \mathrm{M}\right)$ \\
\hline HLA-DR & $72.5 \pm 18.6$ & $120.8 \pm 18.0^{* * *}$ & $77.7 \pm 19.8$ \\
\hline CD86 & $497.4 \pm 26.3$ & $655.9 \pm 42.6^{* *}$ & $490.2 \pm 29.9$ \\
\hline
\end{tabular}

Mature dendritic cells were obtained by culturing cells with LPS $(500 \mathrm{ng} / \mathrm{ml})$ during $24 \mathrm{~h}$ at $37^{\circ} \mathrm{C}$. Then cells were treated during $1 \mathrm{hr}$ with IgG from breast cancer patients in T1NOMx in the absence or presence of the muscarinic antagonist atropine (AT) or the nicotinic antagonist mecamylamine (MM) added 30 min before $\mathrm{lgG}$. The expression of HLA-DR and CD86 was measured by flow cytometry. Data represent the mean \pm S.E.M of 4 experiments. ${ }^{* *} \mathrm{p} £ 0.001 ;{ }^{* * *} \mathrm{p}$ $£ 0.0001$ vs. IgG.

Table 1: Effect of cholinergic antagonists on the IgG-modulated expression of maturation markers in mature dendritic cells.

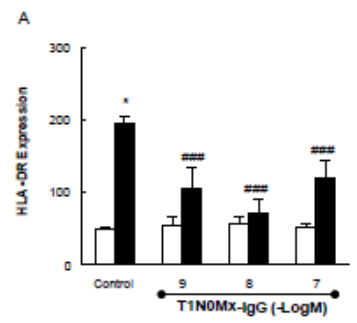

$$
\begin{aligned}
& \mathrm{I}_{\mathrm{MDC}} \mathrm{C} \\
& \mathrm{MDC} \\
&
\end{aligned}
$$
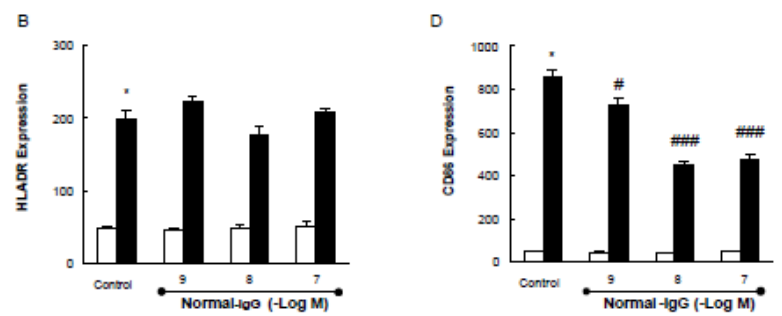

Figure 1: Modulation of the expression of HLA-DR and CD86 on dendritic cells. Cells were obtained from human monocytes as it was stated in Materials and Methods. Then, cells were cultured in the absence or presence of LPS $(500 \mathrm{ng} / \mathrm{ml})$ to obtained inmature (i) or mature $(\mathrm{m})$ dendritic cells (DC) respectively. DC were stimulated during $1 \mathrm{~h}$ with different concentrations of T1N0MxIgG to analyze A) HLA-DR or C) CD86 expression. Also the effect of normal-IgG on B) HLA-DR or D) CD86 expression in DC was analyzed. Markers were measured by flow cytometry. Data represent the mean fluorescence intensity \pm S.E.M. $(n=3)$. ${ }^{*} \mathrm{p}<0.0001$ vs. control iDC; ${ }^{\#} \mathrm{p}<0.01$ and ${ }^{\# \# \#} \mathrm{p}<0.0001$ vs. control $\mathrm{mDC}$.

In addition, T1N0Mx-IgG also decreased the expression of CD86 $(\mathrm{p}<0.0001$ vs. control) a co-stimulatory molecule, which is upregulated in $\mathrm{mDC}$ (Figure. $1 \mathrm{C}$ and $2 \mathrm{~B}$ ), and this effect was also reverted by atropine (10-8M) (Table 1). Surprisingly, normal-IgG also reduced CD86 expression in $\mathrm{mDC}$ (Figure. $1 \mathrm{D}$ ). No effects were exerted by T1N0Mx-IgG or normal-IgG on iDC (Figure 1).

\section{Effect of IgG on the production of cytokines by dendritic cells}

Further, we analyzed the effect of IgG on the production of cytokines by DC. IgG from breast cancer patients reduced the production of TNF- $\alpha$ in $\mathrm{mDC}$ at all concentrations tested (Figure. 3A). The latter effect was reverted by the preincubation of cells with 10-8 M atropine but not by mecamylamine (Table 2). In addition, autoAbs increased TNF- $\alpha$ production by iDC only at $10-8 \mathrm{M}(\mathrm{p}<0.001$ vs. control) effect that was totally blunted by atropine (10-8M) (IgG: 207 $\pm 48 \mathrm{pg} / \mathrm{ml}$; atropine plus IgG: $99 \pm 25 \mathrm{pg} / \mathrm{ml})$. Normal-IgG did not modify TNF-a levels in DC supernatants (Figure $3 \mathrm{~B}$ ).

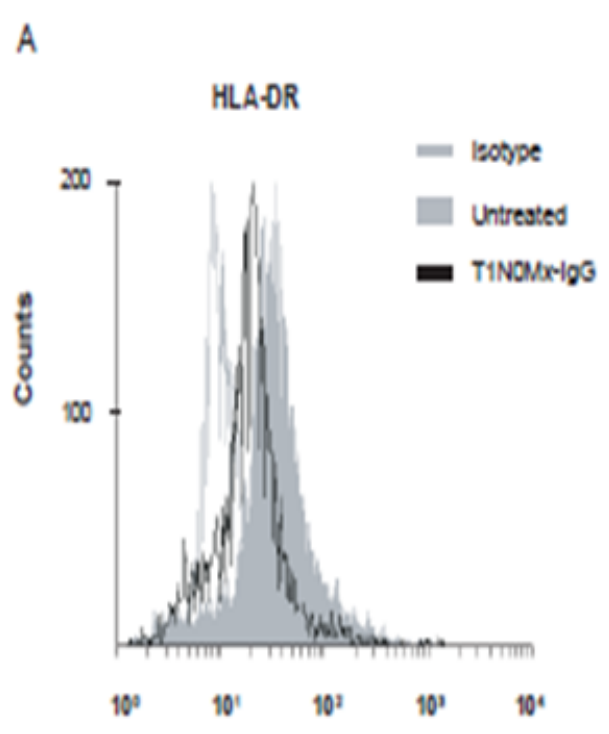

B

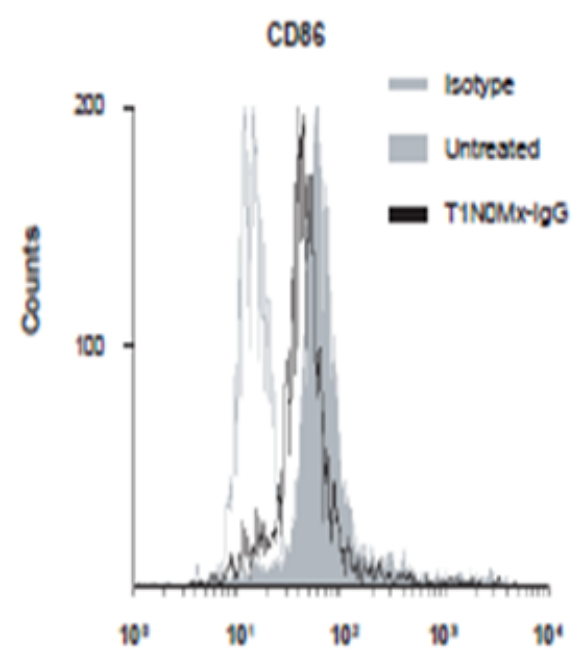

Figure 2: Effect of T1N0Mx-IgG on the expression of HLA-DR and CD86 in mature dendritic cells. Cells were stimulated during $1 \mathrm{~h}$ with 10-8M T1N0Mx-IgG to analyze A) HLA-DR or B) CD86 expression. Histograms from one representative experiment of three are shown. 
Citation: Lombardi MG, Salamone G, Gori S, Oroño MA, Español AJ, et al. (2015) Cholinergic Actions of Autoantibodies from Breast Cancer Patients on Dendritic Cells. J Clin Cell Immunol 6: 340. doi:10.4172/2155-9899.1000340

Page 4 of 6

We also studied the effect of autoAbs on IL-12 production by DC. Figure $3 \mathrm{C}$ shows that IgG from breast cancer patients significantly increased IL-12 levels in $\mathrm{mDC}(\mathrm{p}<0.0001 ; \mathrm{p}<0.001$ vs. control, untreated $\mathrm{mDC}$ ) (Figure. 3C). The effect of $10-8 \mathrm{M}$ IgG was significantly reduced by preincubating cells with mecamylamine (10-8 M) (Table 2). Normal-IgG did not modify IL-12 levels in DC (Figure. 3D).

When we analyzed the effect of autoAbs on IL-10, an increment in this cytokine levels was observed either in $\mathrm{mDC}$ or in iDC at all concentrations tested $(\mathrm{p}<0.01)$ (Figure. $3 \mathrm{E})$. Similarly to IL-12, the preincubation of $\mathrm{mDC}$ with $10-8 \mathrm{M}$ mecamylamine significantly reduced IgG's action on $\mathrm{mDC}(\mathrm{p}<0.001 \mathrm{vs}$. T1N0Mx-IgG) pointing to nAChR participation in these actions (Table 2). Normal-IgG did not exert any effect on IL-10 production by DC (Figure $3 \mathrm{~F}$ ).

\begin{tabular}{|l|l|l|l|}
\hline \multirow{2}{*}{ Cytokine $(\mathbf{p g} / \mathrm{ml})$} & \multicolumn{2}{|l|}{ Treatment } & IgG \\
\cline { 2 - 4 } & $(10-8 \mathrm{M})$ & $\begin{array}{l}\text { IgG }+ \text { AT } \\
(10-8 \mathrm{M})\end{array}$ & $\begin{array}{l}\text { IgG }+\mathrm{MM} \\
(10-7 \mathrm{M})\end{array}$ \\
\hline TNF- $\alpha$ & $2023.3 \pm 494.1$ & $3743.2 \pm 449.5^{*}$ & $2632.4 \pm 301.6$ \\
\hline IL-12 & $761.1 \pm 68$ & $623.3 \pm 134.4$ & $417.4 \pm 109.9^{* \star}$ \\
\hline IL-10 & $376.1 \pm 65.6$ & $318.3 \pm 44.1$ & $193.5 \pm 19.1^{* *}$ \\
\hline
\end{tabular}

Mature dendritic cells were obtained by culturing cells with LPS $(500 \mathrm{ng} / \mathrm{ml})$ during $24 \mathrm{~h}$ at $37^{\circ} \mathrm{C}$. Then cells were treated during $1 \mathrm{~h}$ with $\mathrm{IgG}$ from breast cancer patients in T1NOMx in the absence or presence of the muscarinic antagonist atropine (AT) or the nicotinic antagonist mecamylamine (MM) added $30 \mathrm{~min}$ before $\mathrm{IgG}$. The production of cytokines was measured in cell culture supernatants by ELISA. Data represent the mean \pm S.E.M. of 4 experiments. ${ }^{*} p$ $£ 0.01 ;{ }^{* *} \mathrm{p} £ 0.001$ vs. IgG.

Table 2: Effect of cholinergic antagonists on the IgG-modulated production of cytokines by mature dendritic cells.

\begin{tabular}{|l|l|l|}
\hline Cytokine (pg/ml) & Normal & T1N0Mx \\
\hline TNF-a & $5.2 \pm 1.3$ & $21.9 \pm 8.1^{*}$ \\
\hline IL-12 & N.D. & $43.4 \pm 21.1^{* * *}$ \\
\hline IL-10 & N.D. & $116.1 \pm 42.1^{\star \star \star}$ \\
\hline
\end{tabular}

Blood samples $(10 / 20 \mathrm{ml})$ were obtained at routine procedures before surgery after informed consent from patients classified in stage I (T1NOMx) and from women free of illness (Normal). Sera were separated and heat-inactivated at $56^{\circ} \mathrm{C}$ for $30 \mathrm{~min}$ and stored at $-20^{\circ} \mathrm{C}$. Cytokine levels were determined by ELISA. Results are expressed as mean \pm S.E.M. of 4 experiments. ${ }^{*} p<0.01$; ${ }^{* * *} p<0.0001$ vs. normal sera. N.D: not detected

Table 3: Levels of cytokines in the sera of breast cancer patients in stage I.

\section{Levels of cytokines in the sera of breast cancer patients}

In addition, we analyzed the levels of TNF- $\alpha$, IL-12 and IL-10 in the same sera from which autoAbs were purified. As it is shown in Table 3 , IL-10 and IL-12 which are not detectable in normal sera, dramatically raised in the sera from breast cancer patients $(\mathrm{p}<0.0001$ vs. normal), while a modest increment in TNF- $\alpha$ was observed in the sera form cancer patients ( $\mathrm{p}<0.01$ vs. normal).

\section{Effect of breast tumor on the production of cytokines by dendritic cells}

Taking into account that the presence of tumor could be regulating the activation of DC, we analyzed the effect of MCF-7 tumor extract on iDC regarding the production of cytokines. As it is shown in Table 4 the treatment of iDC with MCF-7 breast tumor proteins $(2.5 \mathrm{mg})$ triggers the liberation of cytokines by iDC reaching similar levels to those observed in $\mathrm{mDC}$, mainly for IL-10 and IL-12 ( $\mathrm{p}<0.0001$ vs. untreated iDC).
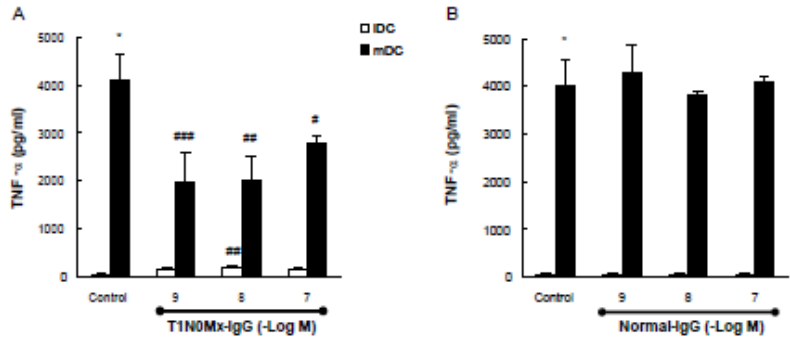

C

D
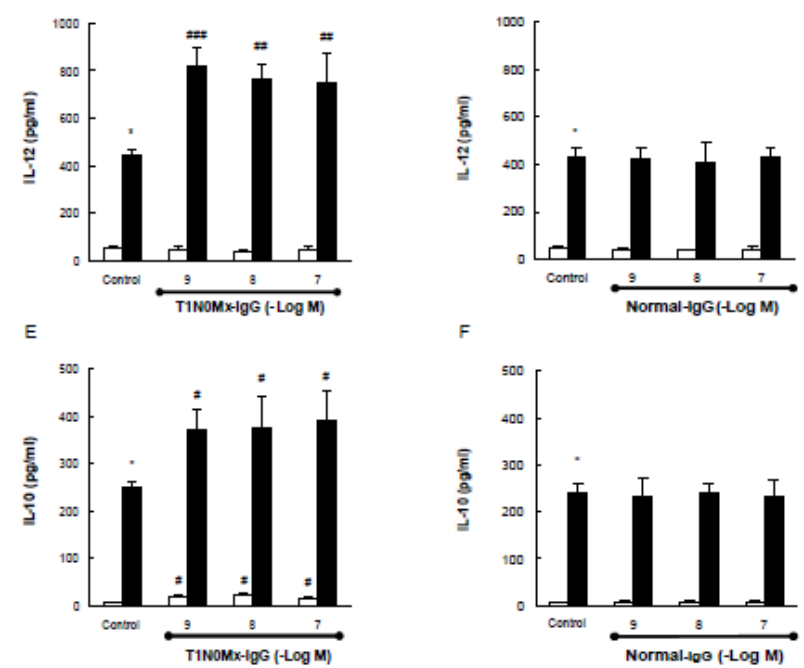

Figure 3: Modulation of cytokine production by dendritic cells. Cells were obtained from human monocytes. Then, cells were cultured in the absence or presence of LPS $(500 \mathrm{ng} / \mathrm{ml})$ to obtain inmature (i) or mature (m) dendritic cells (DC) respectively. DC were stimulated during $1 \mathrm{~h}$ with different concentrations of T1N0Mx-IgG (A,C,E) or normal-IgG (B, D, F) to analyze TNF- $\alpha$; IL-12 or IL-10 respectively in culture supernatants by ELISA. Data are expressed in picograms per milliliter $(\mathrm{pg} / \mathrm{ml})$ and represent the mean \pm S.E.M of 6 experiments. ${ }^{*} \mathrm{p}<0.0001$ vs. iDC; ${ }^{*} \mathrm{p}<0.01$; ${ }^{\# \#} \mathrm{p}<0.001 ;{ }^{\# \#} \mathrm{p}<0.0001$ vs. control iDC or $\mathrm{mDC}$.

\section{Discussion}

The presence of autoAbs against tumor associated antigens in the sera of cancer patients has been reported previously. Several studies reviewed by Fernandez Madrid et al. [12] indicate that a plethora of autoAbs with different specificities have been found in breast cancer patients. These spontaneous responses are frequently detected in 5 to $30 \%$ of patients for one autoantigen. Moreover, Chapman et al. [21] 
reported that the incidence of autoAbs, to at least one of six tumor associated antigens (p53, c-myc, HER2, NYESO-1, BRCA2, and MUC1) analyzed as a group raises to $64 \%$ in the sera of breast carcinoma patients. These striking data imply that the human immune system detects the tumor antigens as "nonself" and makes a humoral immune response very early in this disease.

\begin{tabular}{|l|l|l|l|l|}
\hline Cytokine (pg/ml) & iDC & iDC-bTE & iDC/mDC & $\begin{array}{l}\text { iDC- } \\
\text { bTE/mDC }\end{array}$ \\
\hline TNF-a & $65 \pm 15$ & $240 \pm 44^{* * *}$ & 0.022 & 0.083 \\
\hline IL-12 & $49 \pm 17$ & $190 \pm 41^{\star * *}$ & 0.108 & 0.421 \\
\hline IL-10 & $38 \pm 3$ & $226 \pm 46^{* * *}$ & 0.169 & 1.004 \\
\hline
\end{tabular}

Table 4: Production of cytokines by dendritic cells. Effect of breast tumor extract.

We had described the presence of autoAbs against mAChR in human and animal tumor bearers [13,22]. Our laboratory extensively studied the function of autoAbs from breast cancer patients in stage I as promoters of tumor progression [13-15]. Here, we described for the first time, the ability of autoAbs to stimulate cholinergic receptors expressed in DC exerting modulatory actions. Regarding maturation markers, the decrement in HLA-DR and CD86 molecules induced by autoAbs on $\mathrm{mDC}$ could be revealing a mechanism to produce an immunosuppressive or tolerogenic profile via DC in breast cancer patients. Previous results reported that DC generated from monocytes obtained from early breast cancer patients showed a significantly lower expression of the phenotype-associated antigens CD1a, CD83, CD80, CD86 and CD54 than the DC from healthy controls, which also reinforce our results [23].

We also observed that normal IgG exerted a negative effect on the expression of CD86 in mDC. Antibodies that bind to a variety of exogenous antigens, as well as self-antigens (i.e., nucleic acids, phospholipids, and cellular components), account for a significant proportion of Ig in healthy individuals. These antibodies are referred to as natural antibodies or autoAbs, because they arise independently of known and/or deliberate immunization. Since they recognize a variety of self-antigens, they have a role in the development of the Bcell repertoire and the homeostasis of the immune system [24]. We cannot discard the presence of natural antibodies against cholinergic receptors in healthy donors that could activate cholinergic receptors expressed in iDC.

We observed that IgG from breast cancer patients altered cytokine profile in DC. AutoAbs decreased TNF- $\alpha$ liberation, and stimulated both IL-12 and IL-10 production in mDC. It must be taken into account that it is usually accepted that iDC, after antigen-"danger signal" become into mDC. However, recently it has been reported that after the stimulation with, some drugs, microorganisms, or the tumor microenvironment, iDC differentiation and/or mDC formation could be altered [25-27]. The analysis of tumor infiltrating DC in murine melanoma revealed the presence of myeloid and plasmacytoid DC populations, most of these DC appeared immature, but about a third expressed a mature phenotype [28]. These $\mathrm{mDC}$ might also induce $\mathrm{T}$ cell tolerance, indicating a functional plasticity of $\mathrm{mDC}$ allowing them to adopt either suppressive/tolerogenic or activating/immunogenic phenotypes depending on the signals received [28].

We observed that the stimulation of mDC with IgG from breast cancer patients decreased TNF- $\alpha$ levels and markedly increased IL-12 and IL-10 levels via nAChR activation. In line with our results, NouriShirazi and Guinet [29] proposed that nicotine can exert immunosuppressive effect on immune surveillance through functional impairment of the DC system.

Tolerogenic DC are characterized by a semimature phenotype, with low levels of co-stimulatory molecules expression [30]. Moreover, tolerogenic DC produce high levels of anti-inflammatory cytokines resulting in the induction and expansion of regulatory $\mathrm{T}$ cells [30]. Precisely, the increment in DC-derived IL-10 levels produced by autoAbs added to the inhibition of HLA-DR and CD86 expression could be contributing to the down-regulation of Th1 response and to the up-regulation of Th2 profile with a positive loop on B cells. Concomitantly, IL-10 and IL-12 levels are up-regulated in the sera of breast cancer patients in T1N0Mx, probably as a consequence of the presence of tumor proteins, since the treatment of iDC with MCF-7 tumor extract triggered the production of IL-12, and in a more potent manner of IL-10 almost reaching the levels of these cytokines produced by $\mathrm{mDC}$.

\section{Conclusion}

The results obtained in this work together with our previous observations reveal a central role for cholinergic autoAbs since they promote tumor growth either acting directly on tumor cells or via DC system. Regarding the latter, here we demonstrate that autoAbs modulate the function of DC by reducing maturation markers, as HLA-DR and CD86 and the production of TNF-a, and by increasing the liberation IL-10 and IL- 12 by iDC, which in turn could be worsening anti-tumor immune response in breast cancer patients.

\section{Acknowledgments}

The authors want to thank Drs. Carlos Cresta Morgado and Maria Eugenia Azar from the Mastology Department and Dr. Gabriel Fiszman from the Research Area at the Angel H. Roffo Oncology Institute, University of Buenos Aires. Also want to thank to Mrs. María Ester Castro for her excellent technical assistance. This work was supported by grants from the National Research Council PIP 2012-2014 0108, University of Buenos Aires, UBACYT 2011-2014 0012 .

\section{References}

1. Jemal A, Bray F, Center MM, Ferlay J, Ward E, et al. (2011) Global cancer statistics. CA Cancer J Clin 61: 69-90.

2. Fonseca C, Dranoff G (2008) Capitalizing on the immunogenicity of dying tumor cells. Clin Cancer Res 14: 1603-1608.

3. Atabai K, Sheppard D, Werb Z (2007) Roles of the innate immune system in mammary gland remodeling during involution. J Mammary Gland Biol Neoplasia 12: 37-45.

4. DeNardo DG, Coussens LM (2007) Inflammation and breast cancer. Balancing immune response: crosstalk between adaptive and innate immune cells during breast cancer progression. Breast Cancer Res 9: 212 .

5. Shurin MR (1996) Dendritic cells presenting tumor antigen. Cancer Immunol Immunother 43: 158-164.

6. Bell D, Chomarat P, Broyles D, Netto G, Harb GM, et al. (1999) In breast carcinoma tissue, immature dendritic cells reside within the tumor, whereas mature dendritic cells are located in peritumoral areas. J Exp Med 190: 1417-1426.

7. Chapoval AI, Tamada K, Chen L (2000) In vitro growth inhibition of a broad spectrum of tumor cell lines by activated human dendritic cells. Blood 95: 2346-2351. 
Citation: Lombardi MG, Salamone G, Gori S, Oroño MA, Español AJ, et al. (2015) Cholinergic Actions of Autoantibodies from Breast Cancer Patients on Dendritic Cells. J Clin Cell Immunol 6: 340. doi:10.4172/2155-9899.1000340

Page 6 of 6

8. Kees T, Egeblad M (2011) Innate immune cells in breast cancer--from villains to heroes? J Mammary Gland Biol Neoplasia 16: 189-203.

9. Turk MJ, Wolchok JD, Guevara-Patino JA, Goldberg SM, Houghton AN (2002) Multiple pathways to tumor immunity and concomitant autoimmunity. Immunol Rev 188: 122-135.

10. Finn OJ (2008) Cancer immunology. N Engl J Med 358: 2704-2715.

11. Abken H, Hombach A, Heuser C, Kronfeld K, Seliger B (2002) Tuning tumor-specific T-cell activation: a matter of costimulation? Trends Immunol 23: 240-245

12. Fernández Madrid F, Tang N, Alansari H, Karvonen RL, Tomkiel JE (2005) Improved approach to identify cancer-associated autoantigens. Autoimmun Rev 4: 230-235.

13. Negroni MP, Fiszman GL, Azar ME, Morgado CC, Español AJ, et al. (2010) Immunoglobulin G from breast cancer patients in stage I stimulates muscarinic acetylcholine receptors in MCF7 cells and induces proliferation. Participation of nitric oxide synthase-derived nitric oxide. J Clin Immunol 30: 474-484.

14. Pelegrina LT, Lombardi MG, Fiszman GL, Azar ME, Morgado CC, et al. (2013) Immunoglobulin G from breast cancer patients regulates MCF-7 cells migration and MMP-9 activity by stimulating muscarinic acetylcholine receptors. J Clin Immunol 33: 427-435.

15. Lombardi MG, Negroni MP, Pelegrina LT, Castro ME, Fiszman GL, et al (2013) Autoantibodies against muscarinic receptors in breast cancer: their role in tumor angiogenesis. PLoS One 8: e57572.

16. Salamone G, Lombardi G, Gori S, Nahmod K, Jancic C, et al. (2011) Cholinergic modulation of dendritic cell function. J Neuroimmunol 236 47-56.

17. Romani N, Reider D, Heuer M, Ebner S, Kämpgen E, et al. (1996) Generation of mature dendritic cells from human blood. An improved method with special regard to clinical applicability. J Immunol Methods 196: 137-151.

18. Chen TR (1977) In situ detection of mycoplasma contamination in cell cultures by fluorescent Hoechst 33258 stain. Exp Cell Res 104: 255-262.

19. Hou MM, Chang JW, Pang ST, Chiang YJ, Shen YC, et al. (2010) Characterization of the response of dendritic cells and regulatory $\mathrm{T}$ cells to tumor antigens in patients with renal cell carcinoma. Chang Gung Med J 33: 25-35.

20. Bradford MM (1976) A rapid and sensitive method for the quantitation of microgram quantities of protein utilizing the principle of protein-dye binding. Anal Biochem 72: 248-254.

21. Chapman C, Murray A, Chakrabarti J, Thorpe A, Woolston C, et al. (2007) Autoantibodies in breast cancer: their use as an aid to early diagnosis. Ann Oncol 18: 868-873.

22. Fiszman G, Cattaneo V, de la Torre E, Español A, Colombo L, et al. (2006) Muscarinic receptors autoantibodies purified from mammary adenocarcinoma-bearing mice sera stimulate tumor progression. Int Immunopharmacol 6: 1323-1330.

23. Kichler-Lakomy C, Budinsky AC, Wolfram R, Hellan M, Wiltschke C, et al. (2006) Deficiences in phenotype expression and function of dentritic cells from patients with early breast cancer. Eur J Med Res 11: 7-12.

24. Elkon K, Casali P (2008) Nature and functions of autoantibodies. Nat Clin Pract Rheumatol 4: 491-498.

25. Matsumoto T, Hasegawa H, Onishi S, Ishizaki J, Suemori K, et al. (2013) Protein kinase $\mathrm{C}$ inhibitor generates stable human tolerogenic dendritic cells. J Immunol 191: 2247-2257.

26. Casaravilla C, Pittini A, Rückerl D, Seoane PI, Jenkins SJ, et al. (2014) Unconventional maturation of dendritic cells induced by particles from the laminated layer of larval Echinococcus granulosus. Infect Immun 82: 3164-3176.

27. Stoitzner P, Green LK, Jung JY, Price KM, Atarea H, et al. (2008) Inefficient presentation of tumor-derived antigen by tumor-infiltrating dendritic cells. Cancer Immunol Immunother 57: 1665-1673.

28. Grohmann U, Fallarino F, Puccetti P (2003) Tolerance, DCs and tryptophan: much ado about IDO. Trends Immunol 24: 242-248.

29. Nouri-Shirazi M, Guinet E (2003) Evidence for the immunosuppressive role of nicotine on human dendritic cell functions. Immunology 109: $365-373$.

30. Lutz MB (2012) Therapeutic potential of semi-mature dendritic cells for tolerance induction. Front Immunol 3: 123. 